\title{
PENGARUH MODEL PEMBELAJARAN QUESTION STUDENT HAVE BERBANTUAN MEDIA ANIMASI POWTOON TERHADAP PEMAHAMAN KONSEP MATEMATIKA SISWA KELAS X SMK NEGERI 1 SINGARAJA TAHUN AJARAN 2016/2017
}

\author{
I. M. Y. Suardi, I. M. Suarsana, I. G. N. Pujawan \\ Jurusan Pendidikan Matematika, Universitas Pendidikan Ganesha \\ Singaraja, Indonesia \\ e-mail: yudisuarsa16@gmail.com , suarsana1983@gmail.com ,ngrpujawan@yahoo.com
}

\begin{abstract}
Abstrak
Penelitian ini bertujuan untuk mengetahui apakah pemahaman konsep matematika siswa kelas X SMK Negeri 1 Singaraja yang mengikuti pembelajaran dengan model pembelajaran Question Student Have berbantuan media animasi Powtoon lebih tinggi daripada pemahaman konsep matematika siswa yang mengikuti pembelajaran konvensional. Jenis penelitian ini adalah eksperimen semu dengan desain penelitian post test only control group design. Populasi penelitian ini adalah seluruh siswa kelas X SMK Negeri 1 Singaraja tahun ajaran 2016/2017 semester genap yang terdistribusi ke dalam 15 kelas. Pengambilan sampel dilakukan dengan teknik cluster random sampling untuk memperoleh 2 kelas sebagai sampel penelitian. Sampel pada penelitian ini adalah siswa kelas X TN A sebagai kelas eksperimen dan siswa kelas $X$ TN B sebagai kelas kontrol. Data pemahaman konsep matematika siswa diperoleh menggunakan tes dengan bentuk uraian. Tes normalitas dan homogenitas varians menunjukkan skor berdistribusi normal dan memiliki varians yang homogen. Rata-rata skor pemahaman konsep matematika siswa pada kelas eksperimen adalah 21,277 dan rata-rata skor pemahaman konsep matematika siswa pada kelas kontrol adalah 17,875. Data dianalisis menggunakan Uji-t satu ekor pada taraf signifikan $5 \%$. Hasil uji hipotesis menunjukkan bahwa thitung $=3,5684$ lebih dari tabel $=1,9965$, sehingga $\mathrm{H}_{0}$ ditolak. Sehingga, dapat diambil simpulan bahwa pemahaman konsep matematika siswa kelas X SMK Negeri 1 Singaraja yang mengikuti pembelajaran dengan model pembelajaran Question Student Have berbantuan media animasi Powtoon lebih tinggi daripada pemahaman konsep matematika siswa yang mengikuti pembelajaran konvensional.
\end{abstract}

Kata kunci: model pembelajaran Question Student Have (QSH), media animasi Powtoon, pemahaman konsep matematika.

\begin{abstract}
The aim of this study is to examine whether the mathematical conseptual understanding of students grade X SMK Negeri 1 Singaraja who learned with Question Student Have (QSH) model assisted Powtoon animation media is greater than the conseptual understanding of students who learned with conventional learning method. The study is quasi experimental with post-test only control group design. The population of this study was all students of grade $X$ in SMK Negeri 1 Singaraja in the academic year of 2016/2017 who were distributed into 15 classes. The process of equaliting the population sampel was done by using Anova. Sampling is done by cluster random sampling to achieve 2 classes as study sample. One of the class was X TN A as an experimental group and other class was X TN B as an control group. Student's mathematic conseptual understanding data were got using essay test. The normality and variance homogeny test result show that the scores are normal distributed and have no difference in variance. The data were analyzed by using one tail t-test with significance level of $5 \%$. The result of data analysis shows that the value of test $=3,5684$ greater than table $=1,9965$, so that the null hypothesis is rejected. The
\end{abstract}


conclusion is mathematical conseptual understanding of students who learned with Question Student Have (QSH) model assisted Powtoon animation media is greater than the conseptual understanding of students who learned with conventional learning method.

Keywords: Question Student Have (QSH) model, Powtoon animation media, mathematical conseptual understanding.

\section{PENDAHULUAN}

Pada dasarnya pendidikan merupakan suatu proses yang membantu mengembangkan potensi yang dimiliki oleh manusia sehingga manusia mampu untuk menghadapi perubahan yang terjadi. Pendidikan merupakan hal yang sangat penting, sehingga setiap manusia berhak untuk mendapatkan pendidikan yang tepat.

Pentingnya pendidikan tersebut sejalan dengan fungsi pendidikan yang tertuang dalam Undang-Undang RI No. 20 tahun 2003, tentang Sistem Pendidikan Nasional Bab II pasal 3 yang menyatakan bahwa, "Mengembangkan kemampuan dan membentuk watak serta peradaban bangsa yang bermartabat dalam rangka mencerdaskan kehidupan bangsa, bertujuan untuk berkembangnya potensi peserta didik agar menjadi manusia yang beriman dan bertakwa kepada Tuhan Yang Maha Esa, berakhlak mulia, sehat, berilmu, cakap, kreatif, mandiri, dan menjadi warga negara yang demokratis serta bertanggung jawab".

Matematika menjadi salah satu ilmu dasar yang memegang peranan sangat penting yang erat kaitannya dengan kehidupan sehari-hari. Ibrahim dan Suparni (2008:35) mengungkapkan bahwa, "Matematika merupakan ilmu universal yang mendasari perkembangan teknologi modern, mempunyai peran penting dalam berbagai disiplin ilmu dan memajukan daya pikir manusia". Menurut Suherman,dkk (2003:16), "Matematika adalah ilmu pengetahuan yang diperoleh dengan bernalar". Sejalan dengan hal tersebut, Hudojo (2003:103) mengungkapkan, "Matematika sebagai ilmu yang menelaah bentuk-bentuk atau struktur-struktur yang abstrak dan hubungan antara hal-hal itu". Berdasarkan pemaparan diatas, maka pengertian matematika adalah bidang studi yang berkembang dari proses berpikir manusia yang memegang peranan penting dalam membentuk siswa berkualitas. Oleh sebab itu, seluruh siswa yang menempuh pendidikan diwajibkan mempelajari matematika.

Dalam pembelajaran matematika dikelas, guru hendaknya tidak hanya mampu menguasai materi pelajaran, tetapi juga mampu mengelola kelas dengan baik. Pengelolaan kelas yang baik akan menimbulkan pembelajaran yang aktif, inovatif, kreatif, efektif, dan menyenangkan. Oleh karena itu dibutuhkan inovasi-inovasi baru bagi guru dalam pembelajaran, sehingga pembelajaran yang dilakukan dapat lebih bermakna. Dewasa ini tugas dan peran guru bukan lagi hanya sekedar pemberi informasi (transmission of knowledge), tetapi lebih dari itu yaitu sebagai pendorong belajar agar siswa dapat mengkonstruksikan sendiri pengetahuannya.

Sejalan dengan itu, hal tersebut perlu dilakukan demi tercapainya tujuan utama pembelajaran matematika, seperti yang diungkapkan dalam Peraturan Menteri Pendidikan Nasional No. 22 Tahun 2006 Tentang Standar Isi Pendidikan Dasar dan Menengah, salah satunya yaitu memahami konsep matematika, menjelaskan keterkaitan antar konsep dan mengaplikasikan konsep atau algoritma secara luwes, akurat, efisien, dan tepat dalam pemecahan masalah.

Pemaparan di atas menunjukkan pentingnya bagi seseorang untuk mampu memiliki kemampuan sehingga mencapai tujuan-tujuan dalam bidang matematika. Akan tetapi, kenyataannya pencapaian siswa dalam bidang matematika masih rendah. Menurut PISA (Programme for International Student Assesment) tahun 2015, siswa Indonesia berada pada 
peringkat 64 dari 72 peringkat dengan skor 386. Hasil yang tidak jauh berbeda dari penelitian yang dipublikasikan oleh TIMSS (Trend in Mathematics and Science Study) 2015, Indonesia hanya memperoleh peringat 45 dari 50 negara degan skor 397. Hal serupa juga dapat dilihat dari nilai ratarata UN (Ujian Nasional) matematika tingkat SMK se-Kabupaten Buleleng sangat rendah yang dirangkum pada tabel dibawah.

Tabel 01. Nilai Rata-rata UN Matematika Tingkat SMK se-Kabupaten Buleleng

\begin{tabular}{|c|c|}
\hline Tahun Ajaran & $\begin{array}{c}\text { Nilai Rata-rata UN } \\
\text { Matematika }\end{array}$ \\
\hline $2013 / 2014$ & 42,90 \\
\hline $2014 / 2015$ & 44,72 \\
\hline $2015 / 2016$ & 35,72 \\
\hline
\end{tabular}

(Sumber: Dinas Pendidikan Kabupaten Buleleng)

Berdasarkan beberapa penelitian dan hasil nilai UN, diduga hasil yang kurang memuaskan tersebut diakibatkan oleh pemahaman konsep matematika siswa masih rendah karena pemahaman konsep merupakan dasar bagi siswa untuk mengerti dengan materi yang dipelajari. Jika pemahaman konsep siswa kurang maka siswa akan kesulitan untuk menyelesaikan permasalahanpermasalahan berkaitan dengan materi yang dipelajari. Dengan demikian, salah satu kemampuan yang perlu dikembangkan dengan optimal guna mencapai tujuan pembelajaran matematika adalah pemahaman konsep matematika.

Pemahaman konsep matematika merupakan hal yang paling mendasar dalam pembelajaran matematika seperti yang dinyatakan Hudojo (2003:123) bahwa, "Belajar matematika berarti belajar tentang konsep-konsep dan strukturstruktur yang terdapat dalam bahasan yang dipelajari serta mencari hubungan antara konsep-konsep dan struktur-struktur tersebut". Memahami konsep akan membantu dalam proses mengingat dan membuatnya menjadi lebih efisien. Suatu konsep dapat dibentuk melalui pengalaman langsung dengan objek atau kejadian dalam kehidupan sehari-hari, melalui gambar visual, dan sebagainya. Kemampuan memahami konsep merupakan hal yang paling mendasar dalam pembelajaran matematika. NCTM Principles and Standards for School Mathematics (2000) menyatakan, "Students must learn mathematics with understanding, actively building new knowledge from experience and prior knowledge". Artinya, siswa harus belajar matematika dengan pemahaman, secara aktif membangun pengetahuan baru dari pengalaman dan pengetahuan sebelumnya. Dari pemaparan tersebut, pemahaman konsep matematika perlu untuk dioptimalkan.

Pemahaman konsep siswa dapat dioptimalkan dengan cara merencanakan dan menyusun baik perencanaan, media, dan bahan ajar untuk direalisasikan dalam kegiatan pembelajaran. Perencanaan tersebut dapat diintegrasikan dalam bentuk model pembelajaran. Silberman (2009:23) menyatakan, "Apa yang saya dengar, lihat dan tanyakan atau diskusikan dengan beberapa teman lain, saya mulai paham". Pernyataan tersebut mengindikasikan bahwa model pembelajaran yang dibutuhkan untuk dapat mengoptimalkan pemahaman konsep matematika adalah model pembelajaran yang membuat siswa dapat bertanya, membaca, dan berdiskusi tentang materi yang dipelajari. Model pembelajaran yang diduga mampu memberikan pengaruh positif terhadap pemahaman konsep matematika adalah model pembelajaran Question Student Have.

Model pembelajaran Question Student Have menekankan pada keinginan dan harapan anak didik sebagai dasar untuk memaksimalkan potensi yang mereka miliki. Pada model pembelajaran ini siswa diberikan kesempatan untuk memilih atau menyampaikan pertanyaanpertanyaan secara tertulis, sehingga apa yang dipelajari siswa memang apa yang diinginkan juga oleh siswa dan tentu saja harus sesuai dengan tujuan pembelajaran yang direncanakan. Pertanyaan adalah stimulus yang mendorong siswa untuk berpikir dan belajar. Tujuan siswa dalam memilih atau membuat pertanyaan adalah mendorong siswa untuk berpikir dalam memecahkan masalah suatu permasalahan, menyelediki dan menilai penguasaan siswa tentang bahan 
pelajaran, membangkitkan minat siswa sehingga akan menimbulkan keinginan untuk mempelajarinya dan menarik perhatian siswa dalam belajar. Pembelajaran dalam model Question Student Have memberikan peluang kepada siswa untuk dapat melaksanakan pembelajaran yang menyediakan situasi timbal balik, baik antar siswa maupun antara siswa dengan guru sehingga diduga mampu mengoptimalkan pemahaman konsep siswa diduga lebih baik.

Dugaan tersebut didukung oleh penelitian dari Wiratama (2016) dengan judul penelitian "Model Pembelajaran Kooperatif Tipe Question Student Have untuk Meningkatkan Aktivitas dan Hasil Belajar Fisika Siswa pada Kelas X MIA 1 SMAN 11 Kota Jambi". Hasil yang didapat pada penelitian tersebut yaitu model pembelajaran kooperatif tipe Question Student Have dapat meningkatkan aktivitas dan hasil belajar fisika siswa pada pokok bahasan suhu dan kalor di kelas X MIA 1 SMAN 11 Kota Jambi. Hasil belajar yang baik didasari oleh pemahaman konsep matematika yang baik pula. Untuk mendapatkan hasil belajar yang baik siswa dituntut tidak hanya sekedar menghafal apa yang diberikan namun harus menggunakan konsep-konsep yang dipelajari pada situasi yang lain, oleh sebab itu jika hasil belajar siswa yang baik, maka diperkirakan pemahaman konsep matematika juga baik.

Penerapan model pembelajaran Question Student Have dalam pembelajaran di dalam kelas akan lebih optimal dengan menggunakan media pembelajaran. Media pembelajaran ini berguna untuk menarik perhatian siswa dan meminimalisir kekurangan-kekurangan dalam model pembelajaran Question Student Have. Menurut Miarso (2004) media pembelajaran adalah segala sesuatu yang digunakan untuk menyalurkan pesan serta dapat merangsang pikiran, perasaan, perhatian, dan kemauan siswa sehingga dapat mendorong terjadinya proses belajar. Dalam pembelajaran di kelas guru harus pandai memilih media yang cocok digunakan untuk menyampaikan pesan dan membuat siswa lebih termotivasi.
Media pembelajaran yang diduga mendukung penerapan model pembelajaran Question Student Have adalah media animasi Powtoon. Powtoon merupakan layanan online untuk membuat sebuah pemaparan yang memiliki fitur animasi menarik serta timeline yang mudah dimengerti. Fitur animasi yang dimaksud, diantaranya tulisan tangan, animasi kartun, dan efek transisi yang lebih hidup. Penggunaan animasi yang lebih hidup ini akan membuat siswa lebih terfokus kepada sajian yang diberikan.

Dugaan tersebut didukung oleh penelitian dari Parwati (2016) dengan judul penelitian "Studi Kuantitatif dan Kualitatif tentang Pengaruh Model Pembelajaran Quantum Teaching Berbantuan Media Animasi Powtoon terhadap Pemahaman Konsep Matematika Siswa Kelas VIII SMP Negeri 1 Singaraja" Hasil yang didapat dari penelitian tersebut yaitu model pembelajaran Quantum Teaching berbantuan media animasi Powtoon memberikan pengaruh positif terhadap pemahaman konsep matematika siswa. Media animasi Powtoon menekankan supaya siswa mengetahui dan memahami bentuk nyata dari pembelajaran. Hal tersebut membuat siswa tidak mengkhayal dalam membayangkan suatu konsep yang dipejari sehingga siswa mampu mengungkapkan konsep matematika dengan bahasa yang benar dan mudah dipahami.

Berdasarkan hal tersebut, dipandang perlu untuk mendapatkan bukti empiris tentang pengaruh model pembelajaran Question Student Have terhadap pemahaman konsep matematika siswa berbantuan media animasi Powtoon. Dengan demikian digagas sebuah penelitian yang berjudul "Pengaruh Model Pembelajaran Question Student Have Berbantuan Media Animasi Powtoon terhadap Pemahaman Konsep Matematika Siswa Kelas X SMK Negeri 1 Singaraja Tahun Ajaran 2016/2017".

METODE

Penelitian ini merupakan eksperimen semu (quasi experiment). Penelitian semu dapat digunakan untuk melihat pengaruh yang ditimbulkan dari perlakuan berbeda yang diberikan pada masing-masing 
kelompok, dimana peneliti tidak dapat mengontrol semua variabel dan kondisi eksperimen secara ketat. Populasi dalam penelitian ini adalah seluruh siswa kelas $X$ SMK Negeri 1 Singaraja tahun ajaran 2016/2017 yang berjumlah 535 siswa yang terdistribusi ke dalam 15 kelas.

Sebelum melakukan penarikan sampel, terlebih dahulu dilakukan pengujian kesetaraan terhadap 15 kelompok sampel dengan menggunakan Analisis Varians (ANAVA) satu jalur. Uji kesetaraan ini dilakukan untuk memperlihatkan bahwa sampel populasi yang digunakan setara. Data yang digunakan dalam uji kesetaraan ini adalah nilai ulangan akhir semester ganjil tahun ajaran 2016/2017 kelas X SMK Negeri 1 Singaraja.

Setelah diperoleh kelompok sampel yang setara, penentuan sampel dilakukan dengan teknik cluster random sampling, yaitu pemilihan sampel bukan didasarkan pada individual, tetapi lebih didasarkan pada kelompok, daerah, atau kelompok subjek yang secara alami berkumpul bersama (Suryabrata, 2006). Hasilnya adalah terpilih dua kelas yaitu kelas X TN A dan $X$ TN B. Dari dua kelas tersebut dilakukan pengundian untuk menentukan perlakuan yang diterima masing-masing kelompok sampel. Hasil pengundian adalah sebagai berikut (1) Kelas X TN A sebagai kelompok eksperimen memperoleh perlakuan dengan model pembelajaran Question Student Have berbantuan media animasi Powtoon , (2) Kelas X TN B sebagai kelompok kontrol yang tidak diberi perlakuan khusus, tetapi perlakuan seperti biasanya atau dengan menerapkan pembelajaran secara konvensional.

Variabel bebas dalam penelitian ini adalah model pembelajaran di mana model pembelajaran model pembelajaran Question Student Have berbantuan media animasi Powtoon diterapkan pada kelas eksperimen dan model pembelajaran konvensional diterapkan pada kelas kontrol. Sedangkan variabel terikat dalam penelitian ini adalah pemahaman konsep matematika siswa. Desain penelitian yang digunakan dalam penelitian ini adalah post test only control group design.
Instrumen yang digunakan dalam penelitian ini berupa tes yaitu tes uraian, yang digunakan untuk mengukur pemahaman konsep matematika siswa. Dalam menjawab soal bentuk uraian siswa dituntut menjawab secara rinci, maka proses berpikir, ketelitian, dan sistematika penyusunan dapat dievaluasi.

Setelah instrumen disusun, dilakukan uji coba untuk mendapatkan gambaran secara empirik apakah instrumen penelitian berupa tes pemahaman konsep matematika siswa layak digunakan sebagai instrumen. Uji validitas isi instrumen dilakukan oleh dua orang pakar untuk menguji apakah tes yang dibuat relevan atau tidak. Kemudian dilakukan uji coba dan hasil uji coba tersebut digunakan untuk menguji validitas butir dan reliabilitas isntrumen penelitian. Untuk menguji validitas butir soal uraian digunakan rumus koefisien korelasi product-moment Carl Pearson (Candiasa, 2010) dengan rumus sebagai berikut.

$$
r_{x y}=\frac{N \sum X Y-\left(\sum X\right)\left(\sum Y\right)}{\sqrt{\left(N \sum X^{2}-\left(\sum X\right)^{2}\right)\left(N \sum Y^{2}-\left(\sum Y\right)^{2}\right)}}
$$

Setelah menguji validitas, dilanjutkan dengan pengujian reliabilitas dengan menggunakan Alpha Cronbach sebagai berikut (Candiasa, 2010).

$$
r_{11}=\left(\frac{n}{n-1}\right)\left(1-\frac{\sum \sigma_{i}^{2}}{\sigma_{t}^{2}}\right)
$$

Hasil dari ujicoba menunjukkan bahwa 10 butir soal dari 11 butir soal valid. Butir soal yang valid kemudian diuji reliabilitasnya, diperoleh bahwa reliabilitas tes pemahaman konsep sebesar 0,61 yang tergolong tinggi. Untuk posttest digunakan 8 butir soal. Soal yang dipilih telah memuat keseluruhan indikator materi dan indikator pemahaman konsep matematika.

Sebelum melakukan uji hipotesis, terlebih dahulu dilakukan uji prasyarat yaitu uji normalitas dan uji homogenitas varians. Untuk menguji normalitas sebaran data digunakan Uji Kolmogorov-Smirnov, sedangkan untuk menguji homogenitas varians menggunakan Uji Levene. Jika terbukti data berdistribusi normal dan 
memiliki varians yang homogen, maka untuk menguji hipotesisnya digunakan uji-t satu ekor dengan taraf signifikan $5 \%$ $(\alpha=0,05)$ dengan rumus sebagai berikut.

$$
t_{h i t}=\frac{\bar{Y}_{1}-\bar{Y}_{2}}{\sqrt{\frac{s^{2}}{n_{1}}+\frac{s^{2}}{n_{2}}}}
$$

Dengan,

$$
s_{g a b}^{2}=\frac{\left(n_{1}-1\right) s_{1}^{2}+\left(n_{2}-1\right) s_{2}^{2}}{\left(n_{1}+n_{2}-2\right)}
$$

(Candiasa, 2011)

Pengujian dilakukan dengan bantuan Microsoft Excel 2013. Hipotesis alternatif berbunyi, pemahaman konsep matematika siswa kelas X SMK Negeri 1 Singaraja yang mengikuti pembelajaran dengan model Question Student Have berbantuan media animasi Powtoon lebih tinggi daripada pemahaman konsep matematika siswa yang mengikuti pembelajaran konvensional. Nilai $t_{\text {hitung }}$ dibandingkan dengan harga $t_{\text {tabel }}$ yang diperoleh dari tabel distribusi $t$. Pada taraf signifikansi 5\% $(\alpha=0,05)$ dengan derajat kebebasan $\left(n_{1}+n_{2}-2\right), \quad$ apabila nilai $t_{\text {hitung }}>t_{\alpha\left(n_{1}-1, n_{2}-1\right)}$, maka tidak cukup bukti untuk menerima $H_{0}$.

\section{HASIL DAN PEMBAHASAN Hasil Penelitian}

Rangkuman data pemahaman konsep matematika siswa pada kedua kelompok sampel dapat dilihat pada Tabel 02.

Tabel 02 Hasil Analisis Data Pemahaman Konsep Matematika Siswa

\begin{tabular}{ccc}
\hline \multirow{2}{*}{ Variabel } & \multicolumn{3}{c}{ Kelompok } & Kontrol \\
\cline { 2 - 3 } & Eksperimen & 32 \\
\hline$n$ & 36 & 17,875 \\
\hline $\bar{Y}$ & 21,277 & 3,782 \\
\hline$s$ & 4,046 &
\end{tabular}

Berdasarkan Tabel 02 terlihat bahwa rata-rata skor pemahaman konsep matematika siswa yang mengikuti pembelajaran dengan model pembelajaran QSH berbantuan media animasi Powtoon pada kelompok eksperimen lebih tinggi daripada rata-rata pemahaman konsep matematika siswa pada kelompok kontrol yang mengikuti pembelajaran konvensional.

Sebelum uji hipotesis dilakukan, terlebih dahulu dilakukan pengujian prasyarat yaitu uji normalitas dan homogenitas varians terhadap data skor pemahaman konsep matematika siswa.

Hasil uji normalitas data pemahaman konsep matematika siswa pada kelas eksperimen diperoleh $D_{\text {hitung }}=0,0961<$ $D_{\text {tabel }}=0,1476$ (untuk $\mathrm{N}=36$ pada taraf signifikansi $5 \%$ ), pada kelompok kontrol diperoleh $D_{\text {hitung }}=0,0914<D_{\text {tabel }}=0,1542$ (untuk $n=32$ pada taraf signifikansi $5 \%$ ), maka $H_{0}$ diterima yang berarti data skor pemahaman konsep matematika siswa berasal dari populasi yang berdistribusi normal. Uji homogenitas varians dilakukan dengan Uji Levene. Berdasarkan hasil perhitungan diperoleh bahwa nilai $W=$ 0,319 dan nilai $F_{\text {tabel }}=3,986$. Apabila dibandingkan, nilai $W<F_{\text {tabel. }}$. Dengan demikian $H_{0}$ diterima dan hal tersebut berarti kedua kelompok sampel memiliki varians data pemahaman konsep matematika yang homogen.

Berdasarkan hasil uji normalitas dan homogenitas varians diperoleh bahwa data pemahaman konsep matematika siswa untuk kelas eksperimen dan kelas kontrol berdistristribusi normal dan memiliki varians yang homogen. Maka dari itu, pengujian hipotesis bisa dilakukan dengan menggunakan uji-t satu ekor. Rangkuman hasil pengujian data pemahaman konsep matematika siswa dengan menggunakan uji- $t$ disajikan pada Tabel 03.

\section{Tabel 03 Rangkuman Hasil Uji-t}




\begin{tabular}{|c|c|c|c|c|c|c|}
\hline Kelompok & $\mathbf{N}$ & $\overline{\boldsymbol{Y}}$ & $S_{g a b}^{2}$ & $S_{g a b}$ & $t_{\text {hitung }}$ & $t_{\text {tabel }}$ \\
\hline Eksperimen & 36 & 21,277 & \multirow{2}{*}{15,404} & \multirow{2}{*}{3,924} & \multirow{2}{*}{3,568} & \multirow{2}{*}{1,996} \\
\hline Kontrol & 32 & 17,875 & & & & \\
\hline
\end{tabular}

Berdasarkan Tabel 03 dapat dilihat bahwa $t_{\text {hitung }}=3,568$ dan $\quad t_{\text {tabel }}=1,996$. Oleh karena $t_{\text {hitung }}>t_{\text {tabel }}$ maka $\boldsymbol{H}_{\mathbf{0}}$ ditolak dan $H_{1}$ diterima, berarti pemahaman konsep matematika siswa yang mengikuti pembelajaran dengan model Question Student Have berbantuan media animasi Powtoon lebih tinggi dibandingkan dengan siswa yang mengikuti model pembelajaran konvensional.

\section{Pembahasan}

Berdasarkan hasil analisis terhadap skor pemahaman konsep matematika siswa, diketahui bahwa rata-rata skor pemahaman konsep matematika siswa pada kelas eksperimen adalah 21,277 dan rata-rata skor pemahaman konsep matematika siswa pada kelas kontrol adalah 17,875. Hal tersebut menunjukkan bahwa rata-rata skor pemahaman konsep matematika siswa kelas eksperimen lebih tinggi daripada rata-rata skor pemahaman konsep matematika siswa pada kelas kontrol. Hasil uji hipotesis menggunakan Uji- $t$ menunjukkan $t_{\text {hitung sebesar } 3,5684}$ dan $t_{\text {tabel }}$ sebesar 1,9965 sehingga $H_{0}$ ditolak. Jadi dapat disimpulkan bahwa pemahaman konsep matematika siswa kelas $X$ SMK Negeri 1 Singaraja yang mengikuti pembelajaran dengan model pembelajaran Question Student Have berbantuan media animasi Powtoon lebih tinggi daripada pemahaman konsep matematika siswa yang mengikuti pembelajaran konvensional.

Hasil ini didapat karena model pembelajaran QSH adalah model pembelajaran yang mengoptimalkan keinginan dan kebutuhan dari peserta didik sendiri sehingga akan memaksimalkan potensi yang dimiliki peserta didik. Dalam penerapan model pembelajaran ini siswa diberikan kesempatan untuk bertanya seluas-luasnya yang didapatkan melalui tahapan-tahapan dari model pembelajaran QSH . Tahapan-tahapan dari pembelajaran
QSH berbantuan media animasi Powtoon dapat membantu siswa lebih memahami konsep-konsep dari materi yang telah diajarkan oleh guru.

Tahapan awal pada model pembelajaran QSH yaitu mencermati materi. Materi yang disajikan menggunakan bantuan media animasi Powtoon. Media animasi Powtoon merupakan sebuah aplikasi untuk membuat paparan dengan fitur yang menarik dan pengaturan timeline yang sangat mudah yang hasilnya adalah sebuah video. Fitur animasi yang dimaksud, diantaranya tulisan tangan, animasi kartun, dan efek transisi yang hidup. Media animasi Powtoon dibuat semenarik mungkin sehingga siswa tertarik mengikuti pembelajaran. Media animasi Powtoon memberikan pengalaman yang konkret kepada siswa tentang materi yang disajikan, sehingga siswa menjadi lebih termotivasi, tertarik dan semangat untuk belajar. Pada tahapan ini pula, guru mengkondisikan agar suasana belajar kondusif dan menyenangkan.

Tahapan berikutnya adalah tahapan memilih pertanyaan, siswa diberikan lembaran yang berisi pertanyaanpertanyaan yang telah dibuat oleh guru. Siswa mencentang pertanyaan yang ingin ditanyakan atau siswa dapat menulis pertanyaan jika pertanyaan yang ingin ditanyakan tidak ada dalam daftar pertanyaan. Kemudian lembaran tersebuat diberikan kepada siswa lainnya dalam satu kelompok sampai semua siswa dalam satu kelompok mendapatkan kesempatan untuk mencentang pertanyaan atau menulis pertanyaan. Guru kemudian menghitung banyaknya centang untuk setiap pertanyaan. Pertanyaan yang digunakan untuk diskusi adalah pertanyaanpertanyaan yang paling banyak mendapat centang atau pertanyaan yang dibuat siswa. Pada tahapan memilih pertanyaan, siswa didorong untuk berpikir secara luas 
dan berpikir imaginatif tentang pertanyaan yang mana yang dipilih.

Tahapan berikutnya adalah tahapan diskusi kelompok, pertanyaan yang dibahas pada tahap diskusi adalah pertanyaan yang memang dipilih oleh siswa, sehingga siswa akan menjadi lebih fokus saat pembelajaran karena materi yang memang diinginkan dan dibutuhkan oleh siswa. Pada tahapan ini pula, siswa menyatukan pikirian dan saling melengkapi untuk menyelesaikan permasalahan yang ada. Dalam diskusi kelompok dapat melatih sikap demokratis siswa dalam mengajukan argumen. Dalam tahapan ini guru menjadi fasilitator ketika siswa bertanya atau terlihat bingung, guru memberikan masukan atau penjelasan sehingga diskusi berjalan lancar.

Pada tahapan presentasi, guru meminta salah satu perwakilan kelompok untuk mempresentasikan hasil diskusi kelompoknya. Satu perwakilan dipilih oleh guru secara acak, jadi seluruh siswa harus mempersiapkan dirinya, bukan hanya satu siswa saja. Pada tahapan presentasi siswa merangkum kata-kata sendiri dan melatih keberanian siswa untuk mengungkapkan pendapat di depan umum. Setelah itu, kelompok lain diberikan kesempatan untuk menyampaikan pendapatnya dari materi yang dipresentasikan, disinilah terjadi proses saling bertukar informasi. Dari diskusi antar kelompok inilah siswa dapat melengkapi jawaban siswa yang satu dengan siswa yang lainnya. Sedangkan guru bertindak sebagai fasilitator dalam diskusi dan mengoreksi jika terdapat jawaban yang keliru. Pada akhir pembelajaran guru memberikan penghargaan pada kelompok siswa, dengan cara memberikan tepuk tangan atau nilai tambahan pada siswa/kelompok yang dianggap berprestasi saat pembelajaran. Pemberian penghargaan ini dimaksudkan agar siswa lebih giat belajar dan menjadi motivasi untuk lebih baik dari sebelumnya.

Kontribusi model pembelajaran QSH berbantuan media animasi powtoon terhadap pemahaman konsep siswa, yaitu (1) Siswa mampu menyatakan konsep dengan kata-kata sendiri karena adanya model pembelajaran QSH berbantuan media animasi Powtoon yang senantiasa memberikan kesempatan untuk mengemukakan pendapat serta menuangkan ide-ide terkait materi pelajaran dan video pembelajaran yang memudahkan siswa untuk memahami pelajaran, (2) Siswa mampu mengidenfikasi contoh atau bukan contoh dari konsep yang dipelajari karena terdapat video pembelajaran yang memberikan gambaran yang realistik sehingga memudahkan siswa menerima materi yang dibahas, dan (3) Siswa mampu mengaplikasikan konsep dengan benar dalam berbagai situai karena siswa diberikan kesempatan berlatih untuk menyelesaikan persoalan-persoalan yang diberikan.

Hasil tersebut sejalan dengan penelitian Wiratama (2016) yang menyatakan model pembelajaran kooperatif tipe Question Student Have dapat meningkatkan aktivitas dan hasil belajar fisika siswa pada pokok bahasan suhu dan kalor di kelas X MIA 1 SMAN 11 Kota Jambi. Hasil belajar yang baik didasari oleh pemahaman konsep matematika yang baik pula. Untuk mendapatkan hasil belajar yang baik siswa dituntut tidak hanya sekedar menghafal apa yang diberikan namun harus menggunakan konsep-konsep yang dipelajari pada situasi yang lain, oleh sebab itu jika hasil belajar siswa yang baik, maka diperkirakan pemahaman konsep matematika juga baik.

Terkait dengan media animasi Powtoon, penelitian yang mendukung yaitu penelitian yang dilakukan oleh Parwati (2016) yang menyatakan bahwa model pembelajaran Quantum Teaching berbantuan media animasi powtoon memberikan pengaruh positif terhadap pemahaman konsep matematika siswa kelas VIII SMP Negeri 1 Singaraja. Media animasi Powtoon menekankan supaya siswa mengetahui dan memahami bentuk nyata dari pembelajaran. Hal tersebut membuat siswa tidak mengkhayal dalam membayangkan suatu konsep yang dipejari sehingga siswa mampu mengungkapkan konsep matematika dengan bahasa yang benar dan mudah dipahami. 
Secara umum, pelaksanaan model pembelajaran QSH berbantuan media animasi Powtoon berjalan dengan baik dan sesuai rencana. Walaupun demikian, dalam pelaksanaannya di kelas tidak luput dari adanya kendala-kendala. Adapun kendala-kendala yang dihadapi seperti, kegiatan membaca bersama pada hari jumat sehingga waktu pembelajaran berkurang, sidak yang dilakukan oleh OSIS sehingga pembelajaran menjadi kurang kondusif, latihan megambel yang dilakukan beberapa orang siswa, jaga alfamart yang dilakukan oleh beberapa orang siswa, dan ketersedian speaker yang layak.

\section{SIMPULAN DAN SARAN}

Berdasarkan pembahasan hasil penelitian dan hasil uji hipotesis, terdapat pengaruh positif model pembelajaran Question Student Have berbantuan media animasi Powtoon terhadap pemahaman konsep matematika siswa. Sehingga, dapat diambil simpulan bahwa pemahaman konsep matematika siswa yang mengikuti pembelajaran dengan model pembelajaran Question Student Have berbantuan media animasi Powtoon lebih tinggi daripada pemahaman konsep matematika siswa yang mengikuti pembelajaran konvensional.

Adapun saran yang dapat disampaikan berdasarkan hasil penelitian yang telah dilaksanakan adalah sebagai berikut.

1. Kepada peneliti lain yang tertarik, disarankan untuk melakukan penelitian terhadap model pembelajaran Question Student Have berbantuan media animasi Powtoon dengan populasi yang lebih besar dan materi pembelajaran yang lebih luas untuk mengetahui pengaruh penerapan model pembelajaran Question Student Have berbantuan media animasi Powtoon dalam pembelajaran matematika secara lebih mendalam.

2. Kepada praktisi pendidikan matematika, khususnya guru mata pelajaran matematika diharapkan

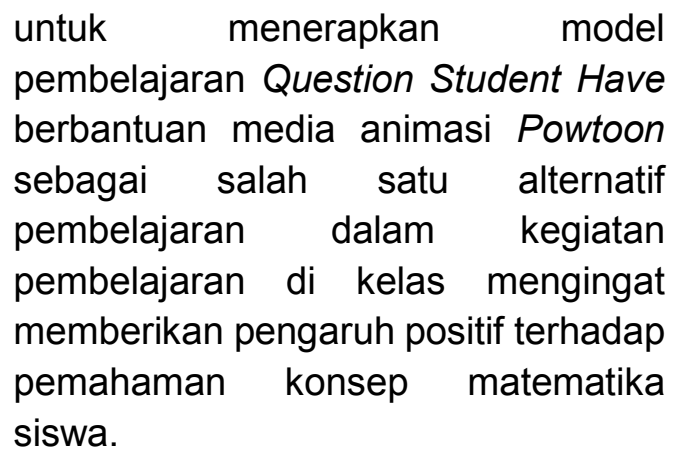

\section{DAFTAR PUSTAKA}

Arikunto, S. 2006. Prosedur Penelitian Suatu Pendekatan Praktik (edisi Revisi VI). Jakarta: Rineka Cipta.

Candiasa, I. M. 2010. Statistik Univariat dan Bivariat Disertai Aplikasi SPSS. Singaraja: Universitas Pendidikan Ganesha.

------. 2011. Pengujian Instrumen Penelitian Disertai Aplikasi ITEMAN dan BIGSTEPS. Singaraja: Universitas Pendidikan Ganesha.

Gulo, W. 2002. Metode Penelitian. Jakarta: PT. Grasindo.

Hamalik, O. 2004. Proses Belajar Mengajar. Jakarta: Bumi Aksara.

Hartono. 2008. PAIKEM Pembelajaran Aktif, Inovatif, Kreatif, Efektif, dan Menyenangkan. Pekanbaru : Zanafa.

Hudojo, H. 2003. Common Textbook: Pengembangan Kurikulum dan Pembelajaran Matematika. Malang: IMSTEP.

Ibrahim dan Suparni. 2008. Startegi Pembelajaran

Matematika.Yogyakarta : Bidang Akademik UIN Sunan Kalijaga.

NCTM. 2000. Principle and Standards for School Mathematic. Virginia: NCTM.

OECD. 2016. PISA 2015 Result in Focus. Tersedia pada https://www.oecd.org/pisa/pisa- 
2015-results-in-focus.pdf (diakses tanggal 5 Februari 2016)

Parwati. 2016. Studi Kuantitatif dan Kualitatif tentang Pengaruh Model Pembelajaran Quantum Teaching Berbantuan Media Animasi Powtoon terhadap Pemahaman Konsep Matematika Siswa Kelas VIII SMP Negeri 1 Singaraja. Skripsi(tidak diterbitkan). Jurusan Pendidikan Matematika, Universitas Pendidikan Ganesha.

Rusman. 2012. Model-Model

Pembelajaran Mengembangkan Profesionalisme Guru. Jakarta: PT Raja Grafindo Persada.

Sanjaya, W. 2006. Strategi Pembelajaran. Jakarta: Kencana Prenada Media Group.

Sardiman. 2010. Interaksi dan Motivasi Belajar Mengajar. Jakarta: PT Rajagrafindo Persada.

Silberman, M. 2009. Active Learning: 101 Cara Belajar Siswa Aktif. Bandung:Nusamedia.

Sugiyono. 2015. Metode Penelitian Pendidikan (Pendekatan
Kuantitatif, Kualitatif, dan R\&D). Bandung: Alfabeta.

Suherman, E., dkk. 2003. Strategi Pembelajaran Matematika Kontemporer. Bandung: JICA.

Sukmadinata. 2009. Metode Penelitian Pendidikan. Bandung: Rosdakarya.

Suryabrata, S. 2006. Psikologi Pendidikan. Jakarta: PT Raja Grafindo Persada.

TIMSS (Trend in Mathematics and Science Study). 2016. International Result in Mathematics . Tersedia pada http://timss2015.org/wp-

content/uploads/filebase/full\%20pd fs/T15-International-Results-inMathematics-Grade-4.pdf (diakses tanggal 5 Februari 2016)

Wiratama. 2016. Model Pembelajaran Kooperatif Tipe Question Students Have Untuk Meningkatkan Aktivitas dan Hasil Belajar Fisika Siswa pada Kelas X MIA 1 SMAN 11 Kota Jambi. Skripsi(tidak diterbitkan). Jurusan Pendidikan Fisika, Universitas Jambi 